\title{
Entre o cárcere e o refúgio: a memória em Sôbolos rios que vão, de António Lobo Antunes
}

Rebeca Leite Fuks

Universidade Federal do Rio de Janeiro

a quantidade de memórias que foi perdendo com o tempo e encontrava espantado, a impressão de se achar no centro do que não sabia o que era e de que a sua vida dependia ${ }^{1}$

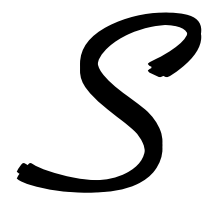

ôbolos rios que vão, livro publicado por António Lobo Antunes, em 2010, é um objeto de estudo que permite ao crítico numerosas possibilidades de investigação. A leitura que faremos nesse artigo privilegiará apenas um aspecto específico da obra: a análise da memória presente no romance.

O livro em questão se estrutura como um diário ficcional e compreende quinze dias corridos dos meses de março e abril de 2007. O protagonista é o senhor Antunes, um homem maduro, que precisará se submeter a uma cirurgia para retirada de um tumor cancerígeno. Durante o período de internação em um hospital de Lisboa, o senhor Antunes se recorda do menino que foi, o Antoninho, e é através dele que a história também passa a ser contada. Portanto, embora o personagem principal se encontre efetivamente no tempo presente, em um hospital, é através do universo pretérito da infância, que boa parte do relato se constrói.

${ }^{1}$ ANTUNES, 2010, p. 89. 
A memória é constantemente evocada neste livro que a todo momento oscila entre o passado e o presente. A fim de recuperar a lembrança de um tempo longínquo e fugir da ameaça assustadora da morte e da doença, Sôbolos rios que vão cria uma atmosfera narrativa híbrida onde dilui as fronteiras de tempo e espaço. De tempo porque mescla pretérito(s) e presente - vejamos como exemplo a seguinte cena:

uma empregada do hotel corrigiu-lhe os pingos do soro e as narinas observadas do travesseiro gigantescas, outra empregada depenava frangos nas traseiras e as plumas espiralavam-lhe à volta de modo que plumas também no hospital sem tombarem ${ }^{2}$

E de espaço ao misturar cenas que os personagens julgam reais com frutos de seus imaginários:

o Virgílio comia no quintal sozinho a cobrir o tacho com os cotovelos de faca pronta a defender o almoço, só havia a serra, não os comboios, não a vila, não ele e começava a perguntar se os médicos verdadeiros e os enfermeiros reais ${ }^{3}$

Partindo por dois caminhos inteiramente distintos, o protagonista divide-se entre o presente, onde figura o senhor Antunes, internado no leito de número onze, e o passado (longínquo - habitado por Antoninho - e recente - simbolizado, principalmente, pela presença da ex mulher Maria Otília). Se, por um lado, a ideia de movimento marca o passado do menino (imagens do comboio chegando e partindo, do gato que desaparece, das brincadeiras de rua), no presente, o senhor Antunes percebe-se totalmente imobilizado na cama do hospital.

${ }^{2}$ ANTUNES, 2010, p. 41.
${ }^{3}$ ANTUNES, 2010, p. 79. 
O diagnóstico do médico é preciso: "Não torna a andar", ${ }^{4}$ no entanto, o senhor Antunes completa: "e afinal andava". ${ }^{5} \mathrm{~A}$ lembrança traz à tona a vida e o movimento que só existiam no passado.

O Dicionário da Obra de António Lobo Antunes já indica esta tendência da memória, retratada pelo autor português, ao colocar, em polos opostos, estagnação e movimento. O verbete "Memória" aponta especialmente para "estas duas potencialidades da memória na escrita de ficção, predominantemente estática ou dinâmica". ${ }^{6}$ E é através desta situação-limite, que obriga o sujeito à reflexão, que brota uma autoconsciência da finitude humana. Diante da inércia que o corpo impõe a ele, seu pensamento vagueia para sítios onde de fato havia vida. Daí surge o gesto de resgatar-se a si próprio, buscando experiências e prazeres que só são possíveis de serem retomados através da memória. Ao analisar as crônicas antunianas, Alexandre Montaury observa como "a memória caracteriza-se, assim, por ser um local de refúgio, adquire um estatuto discursivo e passa a transfigurar o real." ${ }^{\prime 7}$ A escrita que surge como produto da memória é a única saída para o senhor Antunes que busca, desesperadamente, "um episódio antigo que o distraísse de si" ${ }^{8}$ Este rememorar, então pleno de "imprecisões e falhas", ${ }^{9}$ facilmente faz o sujeito embarcar em um cenário de "mistificações". ${ }^{10}$ Andreas Huyssen comenta: "A linha divisória entre o passado mítico e o passado real muitas

${ }^{4}$ ANTUNES, 2010, p. 132.

${ }^{5}$ ANTUNES, 2010, p. 132.

${ }^{6}$ SEIXO, 2008, p. 383.

7 MONTAURY, 2005, p. 106.

8 ANTUNES, 2010, p. 149.

${ }^{9}$ MONTAURY, 2005, p. 106.

${ }^{10}$ MONTAURY, 2005, p. 106. 
vezes não é fácil de traçar. O real pode ser mitologizado, assim como o mítico pode engendrar fortes efeitos." ${ }^{\prime 11}$ Ao estudar diários de convalescentes, Lejeune reafirma a importância deste tipo de relato que pretende manter a lembrança viva durante este momento específico da vida - a ameaça da morte:

Enquanto escrevo, ainda estou vivo. E depois, naquele momento em que meu corpo está sendo destruído, reconstruo-me através da escrita, anotando essa destruição. $\mathrm{Eu}$, que sofro, torno-me novamente ativo, dou a volta por cima. Esse domínio não é imaginário, mesmo se não me poupa da morte. ${ }^{12}$

No presente, o campo semântico mais explorado é aquele que se refere ao medo da morte: "de forma que o pássaro do seu medo continuava aos círculos". ${ }^{13} \mathrm{~A}$ morte, aliás, é um dos grandes temas de Sôbolos rios que vão. A cada página do livro ela está sendo direta ou indiretamente discutida. Já no primeiro parágrafo, na primeira cena, o que se transcreve é a imagem de um funeral, ou melhor, da lembrança que o senhor Antunes guardou de quando assistiu, ainda menino, ao enterro de uma criança ("e um cortejo alongou-se na direcção do cemitério com a urna aberta e uma criança dentro, outras crianças vestidas de serafim de guarda ao caixão" $\left.{ }^{\prime 14}\right)$. Porém, para uma análise um pouco mais aprofundada sobre o tema da morte preferimos selecionar outro fragmento, o presente na página 100 do livro:

(...) e lembrou-se de um amigo do avô, o senhor Hélio, a lutar com os degraus ao domingo, erguia um dos pés,

${ }^{11}$ HUYSSEN apud MONTAURY, 2005, p. 106.

${ }^{12}$ LEJEUNE, 2008, p. 279.

${ }^{13}$ ANTUNES, 2010, p. 12.

${ }^{14}$ ANTUNES, 2010, p. 11. 
agarrado à parede e conquistava o primeiro numa dificuldade trémula, não permitia que o ajudassem

- Faço isto sozinho de pescoço a transbordar da gravata e as narinas enormes, na Páscoa tombou sobre o prato, a meio do almoço, como uma peça de xadrez e o avô na varanda na sua redoma de silêncio, quando a mãe escreveu a notícia devolveu-lhe o papel que não leu, atravessou apenas, como fazia ao jornal, sem uma alteração, calado, tal como ele sem uma alteração, calado, quase à tona da água onde as luzes davam lugar a pessoas, ao erguerem o senhor Hélio da toalha a certeza que o fitava como fitava os degraus avaliando-os zangado e a mãe sem coragem de rasgar o papel por consideração pela morte, muitos anos depois descobriu-o numa gaveta, a lápis, em maiúsculas tortas, entre frasquinhos de verniz, luvas e um puxador antigo que não abria salas, abria mais vazio no vazio, como escrever a morte a não ser em maiúsculas tortas e a mãe cheia de morcegos na alma, quem insiste que os defuntos não vivem não conhece o mundo, o papel deve continuar entre as ruínas da casa ${ }^{15}$

Percebemos, no exemplo anterior, que a mãe de Antoninho não consegue jogar fora o papel em que se anunciava tal morte. O senhor Hélio morre, mas o papel não. Isto porque a escrita mantém a memória do acontecimento viva. Vale lembrar que, no romance, não só o passado do senhor Antunes é retratado. Nele, lêem-se também trechos sobre o passado da avó, a ocasião em que os pais de Antoninho se conheceram, as conversas entre as amigas da mãe de Antoninho, etc. Só através da palavra escrita e da criação desse tempo sem tempo, é que se torna possível o encontro de tantos passados em um mesmo lugar. Em suma, em se tratando de Sôbolos rios que vão, é possível dizer que escrever é a única maneira de não se deixar morrer. Ou como diria

15 ANTUNES, 2010, p. 100. 
Lejeune: "Um caderno no qual nos contamos - ou folhas que mandamos encadernar - é uma espécie de corpo simbólico que, ao contrário do corpo real, sobreviverá." ${ }^{16}$ É através do relato do senhor Antunes que vivem as pequenas narrativas do Virgílio, da dona Irene, da Lucrécia, da Maria Otília, dos avós, do pai, da mãe, do senhor Hélio, entre tantos outros personagens.

Mas, quando afirmamos que o romance de Lobo Antunes trata, a todo momento, da questão da morte, não nos referimos única e exclusivamente àquela morte do corpo físico, o falecimento. Enxergamos essa morte de modo mais amplo. Não por acaso, logo após a cena que descreve o fim do senhor Hélio, existem duas passagens que colocam em questão a noção de perda: a queima do dicionário e a lembrança da traição do pai. Essa associação de imagens aparece na seguinte passagem:

[a avó] desorientada com milhares de palavras de que ignorava o uso, artefacto, diegese, iconoclasta, neonatologia, o universo muito mais amplo do que supunha e o que não conhecia dele, parafernália por exemplo, emboscado em qualquer ponto da casa de mandíbulas abertas, existiriam iconoclastas e artefactos na vila, o que fazer se uma diegese - Anda cá

(...) a avó pediu a empregada que queimasse o dicionário no fogão (...) a cozinheira enterrou as cinzas do dicionário na balsa a seguir à vinha para não estragar a colheita, $\mathrm{o}$ senhor Hélio há séculos no terceiro degrau a abanar a cabeça quando ele morrer estenderiam um papel à mãe e a mãe incapaz de decifrá-lo

- Que é isto?

não é nada senhora, não aconteceu nada, o pai de fato de ténis

${ }^{16}$ LEJEUNE, 2008, p. 264. 
- Não contes à minha mulher por favor quis dizer

- Pai

pediu

- Pai

e perdeu-o (...)

a lembrar-se da história da empregada

- Não contes à minha mulher por favor

e a detestá-lo com fúria ${ }^{17}$

Tudo se inicia quando, angustiada com a imensidão de palavras que um dicionário comporta, a avó decide dar cabo do objeto imaginando que, desta forma, conseguiria dar fim a sua angústia. A morte, no caso, do objeto, precisa existir para que também morra a angústia, inerente à avó, fruto de seu desconhecimento ou ignorância. Essa morte do objeto é tão fundamental para a compreensão da importância do sentimento da avó, que o objeto é enterrado como qualquer ser humano: suas cinzas são depositadas embaixo da terra, longe de qualquer forma de vida, longe da plantação para "não estragar a colheita". Após essa "pequena morte" que convive textualmente ao lado da morte do senhor Hélio há, a nosso ver, a morte simbólica da figura do pai. Embora o pai efetivamente não tivesse morrido, morreu aos olhos do menino Antoninho aquela figura em quem era possível depositar toda a sua confiança.

Apesar de o exemplo anteriormente citado ser útil para demonstrar ao leitor como a ideia da morte vai muito além do óbito do corpo físico, ele não é capaz de abarcar outra observação importante inerente à perda. Em um romance que trabalha todo o tempo com o conceito de memória, é natural que haja um pavor diante do esquecimento. E o esquecimento, neste caso, não se dá

17 ANTUNES, 2010, p. 102-105. 
apenas pelo decorrer do tempo e pelo excesso de idade; alguns medicamentos dados ao senhor Antunes claramente afetam sua consciência (essa constatação é facilmente comprovada no nível da linguagem). Independente do motivo que leve o personagem ao esquecimento, é fundamental problematizarmos o próprio conceito de esquecimento em si. Esquecer-se de um fato implica a impossibilidade de (re)contá-lo, de passá-lo adiante. Em suma, esquecer significa perder. Para falar de um sujeito é preciso falar sobre sua memória. E como tratar da memória que trava uma constante batalha contra o esquecimento? $\mathrm{O}$ gesto empreendido pelo senhor Antunes de escavar sua própria memória evidencia esse processo de perdas e retomadas (como demonstra a epígrafe deste artigo: "a quantidade de memórias que foi perdendo com o tempo e encontrava espantado"18). A escrita que, por vezes, é tecida através das associações livres de ideias também faz emergir informações que pareciam perdidas em meio ao labirinto da memória:

- Amadeu das Neves Pacheco

a tralha que arrastamos Santo Cristo, o que faço com o Amadeu das Neves Pacheco, expulso-o ou permito que se mantenha submerso juntamente com outros nomes e outros sucessos antigos, o médico a guardar o

- Amadeu das Neves Pacheco

num cofre íntimo desembaraçando-se dele, fica para aí junto da dona Anabela Sousa Ferreira sem tinta no cabelo que não deu mostras de o reconhecer ${ }^{19}$

Estamos tratando, portanto, de diversas formas de morte. Ou melhor, de diferentes maneiras de se relacionar com a noção de perda. A própria saída da infância para entrada na vida adulta

\footnotetext{
${ }^{18}$ ANTUNES, 2010, p. 89.

${ }^{19}$ ANTUNES, 2010, p. 58.
} 
implica uma espécie de perda. Como é possível perceber, a escrita deste romance não corrobora com o mito da infância completamente feliz. ${ }^{20} \mathrm{~A}$ infância é tratada em Sôbolos rios que vão como um período de inaugurações e descobrimentos sejam eles prazerosos ou traumáticos: um "mundo da primeira vez" $z^{21}$ Crescer dói e exige uma série de rupturas e desencantos. Este percurso é justamente o que o romance tematiza: não uma infância estagnada, mas um espectro que parte da infância em direção ao amadurecimento do personagem. Contudo, por mais que a descrição precise retratar instantes cruciais e extremamente difíceis, o que salta aos olhos do leitor é a delicadeza e o humor com que essas cenas são entoadas. Vejamos, por exemplo, o momento-chave que registra a transição de uma inocência infantil para o descobrimento da sexualidade:

o primeiro pêlo da barba absurdo, duro, negro, não o cortou com a navalha ao espelho plano de um lado e côncavo do outro, cortou com a tesoura da costura e o pêlo sob o dedo, duas ou três borbulhas, fragmentos até então sonâmbulos nos calções que inchavam, o que se passava comigo, o tio subiu-lhe o selim da bicicleta e os pedais diminutos nas solas, reparou de um modo diferente no peito da cozinheira, inchou numa vontade esquisita de

${ }^{20}$ Lobo Antunes em entrevista afirma: "Tem gente que fala da infância como um lugar onde foi feliz. Não há infâncias felizes! A infância é uma altura infeliz, com todos os conflitos interiores e mudanças. A adolescência é uma época muito complicada para uma menina, para um rapaz; muito complicada, muito dolorosa. Então nós, como temos que viver com algum paraíso perdido, mitificamos a infância, porque não há crianças felizes. Os meninos vivem cheios de angústias e fantasmas que aparecem, às vezes, num sonho, às vezes, na vida real." (ANTUNES apud LAGO, 2012, p. 117).

${ }^{21}$ BACHELARD, 1996, p. 112. 
apertá-la e sentiu-se culpado, observava as camponesas às escondidas, alarmando-se consigo

- O que se passa? ${ }^{22}$

No trecho anterior, o amadurecimento se dá de forma natural. No entanto, o "diário" do senhor Antunes registra também momentos de intensa carga traumática ${ }^{23}$ como a cena em que Antoninho flagra o pai traindo a mãe com a empregada em meio à despensa:

uma terça-feira deu com o pai na despensa, de costas para ele, abraçado à empregada, a avançar a recuar idêntico à bomba do poço no meio das prateleiras de pacotes e frascos, a empregada enquanto os pacotes e os frascos tremiam - Nunca mais acaba senhor?

uma embalagem de sal inclinou-se e tombou, não esqueceria nunca o dedo do pé livre do chinelo a que faltava a unha nem os ganchos do carrapito escorregando de banda, a empregada - Olhe o seu filho a ver-nos

o pai um impulso fundo em que se tornou vários e à medida que se recompunha palavras onde até então suspiros

- O meu filho?

${ }^{22}$ ANTUNES, 2010, p. 76.

${ }^{23}$ Existem diferentes definições para o conceito de trauma. Neste momento gostaríamos de empregar o conceito de trauma elaborado pelo professor Francisco Ramos de Farias: "O acontecimento traumático produz restos: um excesso indizível. Traumática é qualquer situação que transborda à elaboração, para quem sofre e para o praticante. (...) $\mathrm{O}$ trauma fratura o aparelho psíquico (aparelho de linguagem ou de memória), fazendo surgir algo que exige a produção de mecanismos de significação. Como a fratura apresenta um resto de natureza não simbolizável, o trabalho de elaboração será constante: os registros de memória se rearranjam para encontrar um signo de percepção que confira sentido ao traço que foi inscrito, porém não foi fixado para ser simbolizado." (FARIAS, 2008, p. 101). 
a cruzar-se com ele em silêncio arrebanhando os últimos pedaços seus, a camisa que ele conhecia e escuridões impossíveis de decifrar no interior do cinto, não voltaram à nascente do Mondego, não tornou a ouvir

- Sabes?

espiava-o à mesa sentindo que o espiava por seu turno - Aquele não é o meu pai

já não podiam ser amigos nem conseguia orgulhar-se quando ele ganhava ao ténis ${ }^{24}$

É importante ressaltar que todas essas lembranças da vivência da criança foram feitas a posteriori, a partir das elaborações de um adulto. Dito de outra forma, Antoninho só ocupa o espaço textual no presente, graças ao trabalho de recuperação empreendido pela memória do senhor Antunes. Como consequência, o que temos transcrito não é necessariamente aquilo que o menino viveu e, sim, o que a intermediação do adulto permitiu que aflorasse em sua lembrança. O próprio Freud destaca que "Essas cenas infantis não são reproduzidas durante o tratamento [psicanalítico], como lembranças - tanto quanto minha experiência até agora diz -, mas como o resultado de uma construção." ${ }^{25}$ A própria ordenação da memória - o impulso que temos de dar um sentido estabelecendo início, meio e fim ao encadear nossas lembranças - surge de um esforço artificial. A recordação voltada para a infância em Sôbolos rios que vão destaca o fato de a memória não respeitar uma ordenação cronológica:

a costureira acompanhou a mãe na direcção do corredor, lembrava-se de a ouvir cantar

- Que memória a tua

e qual o motivo de os dias serem feitos de episódios assim, os relógios marcam as horas uma a uma mas os dias

${ }^{24}$ ANTUNES, 2010, p. 76.

${ }^{25}$ FREUD apud SELIGMANN-SILVA, 2007, p. 142. 
sucedem-se aos pulos, vão de sábado a quinta e de segunda a sexta semeados de intervalos que a lembrança perdeu ${ }^{26}$

Concordamos com Bachelard ao afirmar que "A história da nossa infância não é psiquicamente datada. As datas são repostas a posteriori; vêm dos outros, de outrolugar, de um tempo diverso daquele que se viveu. Pertencem exatamente ao tempo em que se conta." ${ }^{27}$ A relação que estabelecemos com os outros - aqueles que tanto nos ajudaram a (re)contar nossa própria história - também deve ser problematizada. A citação anterior enfatiza o fato de precisarmos do auxílio dos que conviveram conosco para datar os eventos de nossa vida. Gostaríamos de dar um passo adiante, a partir da reflexão feita por Bachelard: seriam os outros meros assistentes capazes de localizar os eventos da nossa vida cronologicamente? Ou melhor, a função daqueles que nos cercam seria apenas a de ajudar a demarcar nossa história em uma linha do tempo? Cremos que não. Halbwachs, ao estabelecer uma distinção entre as memórias individual e coletiva, observa que a primeira "não está inteiramente isolada e fechada. Para evocar seu próprio passado, em geral a pessoa precisa recorrer às lembranças de outras, e se transporta a pontos de referência que existem fora de si". ${ }^{28}{ }^{29}$ Nossas primeiras recordações só surgem, aliás, a partir do momento em que nos tornamos seres sociais:

${ }^{26}$ ANTUNES, 2010, p. 140.

${ }^{27}$ BACHELARD, 1996, p. 100.

${ }^{28}$ HALBWACHS, 2006, p. 72.

${ }^{29}$ Sob uma perspectiva mais ampla seria possível questionar até o papel da própria linguagem na construção de uma memória individual: "o funcionamento da memória individual não é possível sem esses instrumentos que são as palavras e as ideias, que o indivíduo não inventou, mas toma emprestado de seu ambiente." (HALBWACHS, 2006, p. 72). 
É difícil encontrar lembranças que nos levem a um momento em que nossas sensações eram apenas reflexos dos objetos exteriores, em que não misturássemos nenhuma das imagens, nenhum dos pensamentos que nos ligavam a outras pessoas e aos grupos que nos rodeavam. Não nos lembramos de nossa primeira infância porque nossas impressões não se ligam a nenhuma base enquanto ainda não nos tornamos um ser social. ${ }^{30}$

Portanto, em se tratando da memória, é difícil estabelecer a fronteira entre o pensamento individual e o coletivo, entre a memória daquilo que vivemos e daquilo que nos foi contado. Mas este é apenas um dos aspectos possíveis de serem investigados quando tratamos do tema da recordação. Halbwachs propõe uma abordagem e aponta para um caminho interessante a ser percorrido. No entanto, optamos por seguir através de outras possibilidades teóricas. Em comum, Halbwachs e Freud compartilham a crença de que a memória é como um construto. A concepção de Halbwachs é a de que a memória é uma construção social. Freud enxerga a memória como construção, mas a partir de uma outra lógica de pensamento, aquela que embasou a Psicanálise:

Freud nos diz que as lembranças infantis são essencialmente visuais $^{31}$ (...) Ora, as lembranças visuais são, essencialmente,

${ }^{30}$ HALBWACHS, 2006, p. 43.

${ }^{31}$ Freud e Bachelard parecem estar de acordo quando afirmam que as lembranças da infância são essencialmente visuais: "Nos devaneios da criança, a imagem prevalece acima de tudo. As experiências só vêm depois. Elas vão a contravento de todos os devaneios de alçar vôo. A criança enxerga grande, a criança enxerga belo. $\mathrm{O}$ devaneio voltado para a infância nos restitui à beleza das imagens primeiras. Pode o mundo ser tão belo agora? Nossa adesão à beleza primeira foi tão forte que se o devaneio nos transporta às nossas mais caras lembranças, o mundo atual parece totalmente descolorido." (BACHELARD, 1996, p. 97). 
lembranças encobridoras, e o processo de condensação implica, justamente, em intensificar um aspecto delas. Por consequência, nossas lembranças da infância nunca remontam diretamente aos fatos tais quais eles foram, pois são inseparáveis dos mecanismos acima apontados, que expressam $a$ ação do esquecimento e a substituição de impressões chocantes $e$ desagradáveis. Elas são uma "tradução", ou uma "transposição" do passado, a partir da posição do sujeito no presente. Elas não exprimem uma "reconstrução" do passado "tal qual ele foi", ou "um eterno retorno do mesmo", mas exigem o trabalho penoso de sua "construção". ${ }^{32}$

A partir das leituras de Freud comprovamos que, no fundo, não há garantias de transcrição tal qual o evento foi vivido por Antoninho cinquenta, sessenta anos antes. Em Psicanálise, recordar significa reconstruir. Até mesmo porque "nossas lembranças da infância não nos mostram os primeiros anos de vida como eles foram, mas como se apresentam, posteriormente, na época de sua evocação." ${ }^{33}$ Isto sem contar o grande papel que a imaginação tem no processo de rememoração. É difícil definir a fronteira entre o que vivemos e o que imaginamos ter vivido, entre o que lembramos a partir de fragmentos e o que nos contaram. A tríade memória-imaginação-recordação apresenta contornos tênues. O próprio Lobo Antunes tece uma observação a esse respeito em entrevista dada a María Luisa Blanco:

Porque não se inventa nada, a imaginação é a maneira como se arruma a memória. Tudo tem a ver com a memória. Agora, os neurologistas estão a realizar numerosos estudos para estabelecer a conexão entre memória e imaginação. Recordo que quando José Cardoso

\footnotetext{
32 SELIGMANN-SILVA, 2007, p. 141-142, grifo nosso.

${ }^{33}$ FREUD apud SELIGMANN-SILVA, 2007, p. 131.
} 
Pires ficou sem memória devido àquela doença, ficou imediatamente sem imaginação. É curiosa a conexão tão íntima que há entre as duas coisas. Se não temos memória, não podemos ter imaginação. Creio que a memória não tem apenas a ver com o passado; também tem a ver com o presente e talvez com o futuro. ${ }^{34}$

Bachelard, em um capítulo dedicado exclusivamente aos Devaneios voltados para a infância, também observa:

Em sua primitividade psíquica, Imaginação e Memória aparecem em um complexo indissolúvel. Analisamo-las mal quando as ligamos à percepção. $\mathrm{O}$ passado rememorado não é simplesmente um passado da percepção. Já num devaneio, uma vez que nos lembramos, o passadoé designado como valor de imagem. A imaginação matiza desde a origem os quadros que gostará de rever. Para ir aos arquivos da memória, importa reencontrar, para além dos fatos, valores. (...) Para reviver os valores do passado, é preciso sonhar, aceitar essa grande dilatação psíquica que é o devaneio, na paz de um grande repouso. Então a Memória e a Imaginação rivalizam para nos devolver as imagens que se ligam à nossa vida. ${ }^{35}$

Caminhando ao lado de Bachelard concluímos que:

Quanto mais mergulhamos no passado, mais aparece como indissolúvel o misto psicológico memória-imaginação. Se quisermos participar do existencialismo do poético, devemos reforçar a união da imaginação com a memória. ${ }^{36}$

A própria construção narrativa e linguística do livro deixa entrever uma confluência de imagens do passado com imagens

34 ANTUNES apud BLANCO, 2002, p. 21.

${ }^{35}$ BACHELARD, 1996, p. 99.

36 BACHELARD, 1996, p. 114. 
do presente, imagens que corroboram com o real e imagens que parecem fruto de um delírio. Este gesto, a propósito, é típico da escrita antuniana. Como afirma João Lobo Antunes, em seu ensaio sobre Sôbolos rios que vão, presente no Jornal de Letras de Lisboa:

A leitura é ainda exigente (...) pela necessidade de não largar o fio do tempo narrativo, pois este obriga os olhos da inteligência a mirarem simultaneamente uma dúzia de écrans que revelam cenas diferentes que ocorrem em tempos distintos em caótica diacronia. ${ }^{37}$

Ou como comenta Diana Navas, em uma perspectiva mais ampla:

Jogando com o passado e o presente, o autor monta um impressionante mosaico de situações, com recuos, adiantamentos, nos quais os streams of consciouness se sucedem em ondas vertiginosas, dando ao leitor a sensação de um grande delírio controlado (assim Lobo Antunes define o ato de escrever), que afinal se evidencia na complexidade e rigor estruturais de seus romances. ${ }^{38}$

Há uma simultaneidade temporal e espacial facilmente identificável, após a leitura das primeiras linhas de Sôbolos rios que vão. Na escrita de Lobo Antunes, encontramos um só tempo. Um tempo que compreende passado (ou melhor, vários passados) e presente onde as cenas confluem. Na cena que será lida a seguir, um encontro amoroso do passado se confunde com o instante da coleta de sangue no hospital, o que leva o narrador-protagonista a estabelecer um paralelo entre as picadas da agulha (tempo presente), e as do broche e do

\footnotetext{
${ }^{37}$ ANTUNES, 2012, p. 17.

${ }^{38}$ NAVAS, 2007, p. 49.
} 
gancho do cabelo (tempo passado). A própria ausência explícita da transição temporal, na enunciação discursiva, mostra-nos a superposição dos fatos vividos em tempos diferenciados. A intenção é justamente esta. Algumas situações simplesmente invadem a consciência do personagem e provocam associações inesperadas.

e a boca dela um rastro de caracol no seu peito - Não foges mais pois não?

Algemando-o numa doçura ansiosa que fazia nascer um ventre inesperado do seu ventre, o broche da senhora picava-o, um gancho do cabelo picava-o, o enfermeiro para o pingo no sapato

- Não lhe encontro a veia

$\mathrm{E}$ a aresta do anel

- Não foges mais pois não? ${ }^{39}$

É com uma delicada sutileza que Lobo Antunes conduz o leitor e o apresenta a um tempo sem tempo. Um tempo que nunca é claro, datado, um presente ou um passado definitivo. Tudo se mistura e o Antoninho é uma imagem fluida, que se confunde com a do senhor Antunes, embaralhando as experiências vividas quando criança com a realidade do hospital. Inclusive, as vozes narrativas se superpõem e se alternam. Não é raro, a meio do parágrafo, por exemplo, sem nenhum aviso prévio, o avô tomar a palavra e ocupar o espaço textual e, dessa maneira, a sua intervenção acaba coexistindo com a fala do narrador-protagonista:

o tempo dos relógios antigos sem relação com o nosso dado que as horas já foram maiores, os defuntos continuavam numa existência paralela a esta em que os móveis estalam de maneira esquisita e o líquido das jarras se oxida, o avô

${ }^{39}$ ANTUNES, 2010, p. 128. 
- Quem são vocês?

sem compreender a que época pertencia, à da madrinha e da mãe ou à nossa, será meu neto o do hospital com uma bola de ténis que o enfermeiro lhe entrega, não um comprimido ${ }^{40}$

Sobre essa intromissão de vozes alheias no texto antuniano, Chagas comenta:

Dentre as múltiplas vozes que, de forma cronológica e sincopada, vão intervindo na trama textual, uma se impõe como comum a todos os narradores - a voz da memória. Todas as personagens intervenientes na obra irão reconstruir o outro através da voz da recordação. O outro surge, assim, não como o ser real, mas como o ser evocado. ${ }^{41}$

Essa definição, usada a princípio para caracterizar outros livros do autor, também pode ser usada para descrever a escrita de Sôbolos rios que vão. Ainda sobre a memória, Ana Paula Arnaut, ao analisar o romance, afirma:

Fazendo prova de que a memória é, de facto, intrigante, confundem-se e fundem-se tempos e espaços, cheiros e cores, verdades e invenções, mortes e vidas e respirações (das coisas e das pessoas), ele e o(s) outro(s) narrador(es) que o substitu[i](em) na sua capacidade de recordar. E nessa (con)fusão, o dono do hotel dos ingleses é o médico que lhe aponta o ouriço no fígado. ${ }^{42}$

A infância figura no livro, de modo geral, como uma válvula de escape, um lugar de calmaria onde a morte parece não conseguir vir assombrar o senhor Antunes. Nas doces palavras do romance: "em criança tinha a certeza de não morrer

\footnotetext{
${ }^{40}$ ANTUNES, 2010, p. 20, grifo nosso.

${ }^{41}$ CHAGAS, 2004, p. 175.

${ }^{42}$ ARNAUT, 2011, p. 1.
} 
nem se tornar um retrato que um suspiro emoldura" ${ }^{43}$ Por isso, a imagem do comboio partindo surge diversas vezes durante a narrativa, salvando o protagonista das longas noites e dos exames intermináveis no hospital: "e a Clínica um comboio Lisboa fora na direcção da serra, que é da certeza de não morrer". ${ }^{44}$ Assim como a voz do pai, que permeia o diagnóstico do médico:

o pingo no sapato a seguir um gráfico

- Não se entende esta febre

o correio, o mercadorias, o rápido, aqueles que furavam a noite feitos de sombras e janelas, o relógio da estação que se atrasava sempre deslocou um ponteiro e certíssimo, a sua vida certíssima, a roupa no armário ao alcance da mão, não me segrede

- Sabes $?^{45}$

Lobo Antunes inaugura sua carreira literária com um romance que carrega no título a palavra que perseguirá toda sua obra: memória. Desde Memória de elefante (1979) encontramos um texto que se dedica a investigar os bastidores da memória (suas dobras, lacunas, motivações). Em Sôbolos rios que vão esta inquietação permanece a mesma. O protagonista é contaminado por uma espécie de nostalgia e sucede exatamente o que Eduardo Lourenço descreve em poucas palavras: "Não é o eu que contempla a saudade, analisa-a ou joga com ela; é ela que faz dele joguete, que o avassala: o eu converte-se, por inteiro, em saudade." 46

${ }^{43}$ ANTUNES, 2010, p. 47.

44 ANTUNES, 2010, p. 48.

${ }^{45}$ ANTUNES, 2010, p. 69, grifo nosso.

${ }^{46}$ LOURENÇO, 1999, p. 33. 
Na grande maioria dos momentos, para que o passado do menino Antoninho possa ser invocado, o narrador faz menção a algum elemento sensorial que provoca sua lembrança e desperta nele o desejo de evasão do presente. O efeito sinestésico está sempre a serviço de uma memória que procura recuperar tempos passados. Não é raro encontrar trechos onde, a partir da lembrança de um único sentido, se recupera uma cena inteira. A memória é suscitada por uma faísca de recordação que pode surgir a partir do sabor de uma compota de doce da avó, da imagem de um caderno de caligrafia antigo, etc. Muitos são os exemplos passíveis de se encontrar, por isso apresentaremos, apenas a título de ilustração, uma passagem associada a cada um dos sentidos:

(visão) como este quarto é branco e que inquietante o branco (...) tudo negro e branco, que é das restantes cores ${ }^{47}$ (olfato) o cheiro do seu nervoso anulava o cheiro do hospital sem anular o cheiro das compotas ${ }^{48}$

(audição) gente de que notava apenas o ruído das botas e portanto não gente, solas e solas ${ }^{49}$

(paladar) fazia-lhe jeito um rato de chocolate para suportar o medo, não fiques com o rato na palma, come-o ${ }^{50}$

(tato) lembrou-se da avó a acariciar-lhe a nuca ${ }^{51}$

Embora os cinco sentidos se complementem para ajudar a traçar um mapa da infância do menino, cremos que o olfato possui uma importância especial. O Dicionário da Obra de

\footnotetext{
${ }^{47}$ ANTUNES, 2010, p. 85.

${ }^{48}$ ANTUNES, 2010, p. 16.

${ }^{49}$ ANTUNES, 2010, p. 11.

${ }^{50}$ ANTUNES, 2010, p. 48.

${ }^{51}$ ANTUNES, 2010, p. 48.
} 
António Lobo Antunes registra a respeito do verbete "cheiro", a seguinte informação:

É o sentido mais fortemente associado à memória, que apresenta registros de uma grande complexidade, oscilando entre o papel desempenhado pela famosa madalena de Proust, e o seu inverso. (...) mas é igualmente a memória que presentifica o cheiro. ${ }^{52}$

Ao escrever sobre a recordação voltada para a infância, Bachelard também enfatiza o papel do cheiro ao observar que o odor é o "primeiro testemunho da nossa fusão com o mundo"53 e, por isso, toda "infância é um feixe de odores." ${ }^{\text {" } 4}$ No romance que vem sendo estudado, a memória se apresenta de maneira tão intensa que é capaz de recuperar um cheiro do passado. Diferente de outros romances, onde um cheiro arrebata a memória do personagem de maneira incontrolável, provocando a recordação, em Sôbolos rios que vão, o protagonista, encerrado em um asséptico ambiente hospitalar, sequer pode se dar ao luxo de ter seu cotidiano interrompido por um cheiro real que sirva como adubo para sua rememoração. Resta a ele viajar através de um imaginário delirante.

Em uma passagem presente no romance Conhecimento do inferno (1981), o narrador-protagonista tematiza justamente esta relação entre o olfato, a memória e a imaginação:

Os odores são normalmente desatentos: cruzam-se connosco numa pressa atarefada, demoram-se uns segundos, e desvanecem-se no ar à maneira dos sorrisos que pairam, adiante das bocas, como as sombras que rodeiam a casa onde

${ }^{52}$ SEIXO, 2008, p. 114.

${ }^{53}$ BACHELARD, 1996, p. 132.

${ }^{54}$ CHADOURNE apud BACHELARD, 1996, p. 132. 
nascemos de um véu difuso de mistério. Em menino distinguia os aromas numa agudeza pronta de cão, pressentia pelo olfacto a chegada das pessoas antes de lhes escutar os passos no corredor ou no vestíbulo, adivinhava os que iam morrer através do halo gorduroso que os envolvia, pesado já do relento estranho dos cadáveres. Depois, ao crescer, ganhei o que os adultos chamam «o sentido prático da vida», que finca no fundo o automatismo da inutilidade, e perdi o dom da atenção afectuosa e alarmada das crianças, em que ecoam, como nos sonhos, os enormes passos misturados da alegria e do pavor. Até que no quarto de hotel em Armação de Pêra, cujas paredes cintilavam de luz, após muitos dolorosos, e felizes, e carregados de fé, e desesperados dias, vi o odor do mar sentado no parapeito a olhar-me, com as suas pupilas humildes de cavalo. ${ }^{55}$

A associação feita em Conhecimento do inferno entre a memória e o cheiro que é capaz de despertá-la está presente nas reflexões da pesquisadora argentina Beatriz Sarlo, na célebre passagem em que afirma:

Propor-se não lembrar é como se propor não perceber um cheiro, porque a lembrança, assim como o cheiro, acomete, até mesmo quando não é convocada. Vinda não se sabe de onde, a lembrança não permite ser deslocada; pelo contrário, obriga a uma perseguição, pois nunca está completa. A lembrança insiste porque de certo modo é soberana e incontrolável (em todos os sentidos dessa palavra). Poderíamos dizer que o passado se faz presente. E a lembrança precisa do presente porque, como assinalou Deleuze a respeito de Bergson, o tempo próprio da lembrança é o presente: isto é, o único tempo apropriado para lembrar e, também, o tempo do qual a lembrança se apodera, tornando-o próprio. ${ }^{56}$

55 ANTUNES, 1979, p. 42.

56 SARLO, 2007, p. 10. 
Esta apropriação que a lembrança promove no tempo presente fica bastante evidente na escrita antuniana. Mais do que um gesto natural de lembrar, é notório que a memória representada no romance se apresente como um passado que não passa, que emerge e retorna sempre ao mesmo ponto. Rememorar se trata, sobretudo, de um ato persistente (tanto para o bem quanto para o mal). A memória apresentada por Lobo Antunes, neste romance, se aproxima muito do arquétipo do labirinto, tanto a partir da enunciação discursiva - a escrita é toda trabalhada de modo entrelaçado, intrincado, sem percursos claros e sem possibilidade de saída - quanto a partir da postura emocional do sujeito que se encontra às voltas sempre com as mesmas e repetidas lembranças (sejam elas ternas ou amargas). Sozinho, o senhor Antunes se volta para os meandros da memória e caminha só. Retomamos novamente a reflexão de Bachelard:

A síntese que é o sonho labiríntico acumula, ao que parece, a angústia de um passado de sofrimento e a ansiedade de um porvir de infortúnios. O indivíduo fica preso entre um passado bloqueado e um futuro obstruído. Fica aprisionado num caminho. Enfim, estranho fatalismo do sonho de labirinto: volta-se às vezes ao mesmo ponto, mas jamais se volta para trás. ${ }^{57}$

E este não seria justamente o drama subjetivo descrito em Sôbolos rios que vão? O senhor Antunes, fixado num presente de ansiedade e medo, não consegue vislumbrar um futuro para si e não pode mais voltar a um passado que já foi vivido ("o passado remoto, o presente alheio, o futuro inexistente" ${ }^{\prime 58}$ ). A escrita labiríntica entra então a serviço de uma memória

${ }^{57}$ BACHELARD, 2003, p. 164.

${ }^{58}$ ANTUNES, 2010, p. 52. 
também labiríntica: "a cozinheira igual, que intrigante a memória, a tirar-lhe uma caixa onde pulavam sons / - Se brinca com os fósforos faz chichi na cama". ${ }^{59}$

Retomando o título deste trabalho, a memória representada em Sôbolos rios que vão pode ser identificada ao mesmo tempo com a ideia do refúgio e do cárcere. Carregada por um notável grau de nostalgia, a memória se faz refúgio porque é capaz de exorcizar o medo da mortee da doença. Simultaneamente ela se dá a ver como obsessiva e faz do personagem uma espécie de refém porque opera a partir de uma lógica labiríntica obrigando o sujeito a uma série de repetições e retornos a lembranças, inclusive as traumáticas.

Esta memória obsedante que insiste, persiste e repete ilustra perfeitamente uma célebre passagem de Walter Benjamin presente em Obras Escolhidas II: Rua de Mão Única. Para o teórico,

Quem pretende se aproximar do próprio passado soterrado deve agir como um homem que escava. Antes de tudo, não deve temer voltar sempre ao mesmo fato, espalhá-lo como se espalha a terra, revolvê-lo como se revolve o solo. Pois "fatos" nada são além de camadas que apenas à exploração mais cuidadosa entregam aquilo que recompensa a escavação. ${ }^{60}$

O gesto de escavar os meandros da memória, empreendido pelo senhor Antunes, lhe rende um belo diário e uma viagem ao passado. O livro, que é um cântico de lamento pelo fim - pela morte -, pode ser simultaneamente lido como uma ode e uma homenagem à vida, à recordação e à infância. Duas faces de uma mesma moeda: a vida - que impõe a doença e a consciência da finitude-éa mesma que fornece instrumentos para este mergulho em si próprio através da lembrança.

\footnotetext{
${ }^{59}$ ANTUNES, 2010, p. 74, grifo nosso.

${ }^{60}$ BENJAMIN, 1985, p. 239.
} 


\section{Referências}

ANTUNES, António Lobo. Sôbolos rios que vão. Lisboa: Dom Quixote, 2010.

ARNAULT, Ana Paula. Sôbolos Rios que Vão de António Lobo Antunes: quando as semelhanças não podem ser coincidências. Disponível em: http:/ / ala.t15.org/livros/25SR_arnaut.pdf Acesso em: 25 mai. 2011.

BACHELARD, Gaston. A poética do devaneio. Trad. Antônio de Pádua Danesi. São Paulo: Martins Fontes, 1996.

BACHELARD, Gaston. A terra e os devaneios do repouso. Trad. Paulo Neves. São Paulo: Martins Fontes, 2003.

BENJAMIN, Walter. Escavando e recordando. In: Obras Escolhidas II: Rua de Mão Única. Trad. Rubens Rodrigues Torres Filho e José Carlos Martins Barbosa. São Paulo: Brasiliense, 1985.

CHAGAS, Maria Manuela Duarte. Da multiplicidade de vozes narrativas à incomunicabilidade - tópicos da visão do mundo de Lobo Antunes na construção de sensibilidades contemporâneas. In: CABRAL, Eunice; JORGE, Carlos J.F.; ZURBACH, Christine (Org.). A escrita e o mundo em António Lobo Antunes - Actas do Colóquio Internacional António Lobo Antunes da Universidade de Évora. Lisboa: Dom Quixote, 2004.

FREUD, Sigmund. Além do princípio de prazer, Psicologia de grupo e outros trabalhos. Trad. Luiz Alberto Hanns. Rio de Janeiro: Imago Editora, 1976.

HALBWACHS, Maurice. A memória coletiva. Trad.Beatriz Sidou. São Paulo: Centauro, 2006.

LEJEUNE, Philippe. O pacto autobiográfico. Trad. Jovita Maria Gerheim Noronha e Maria Inês Coimbra Guedes. Belo Horizonte: Editora UFMG, 2008.

LOURENÇO, Eduardo. Mitologia da saudade seguido de Portugal como destino. São Paulo: Companhia das Letras, 1999. 
MONTAURY, Alexandre. Testemunho e ficção: os lugares da fala na obra de António Lobo Antunes. Tese de Doutorado. Rio de Janeiro: PUC-RJ, 2005.

NAVAS, Diana. Narcisismo discursivo e metaficção em Lobo Antunes: uma leitura de Não entres tão depressa nessa noite escura. Dissertação de Mestrado. São Paulo: PUC-SP, Faculdade de Letras, 2007.

SARLO, Beatriz. Tempo passado: cultura da memória e guinada subjetiva. Trad. Rosa Freire d'Aguiar. São Paulo: Companhia das Letras; Belo Horizonte,: UFMG, 2007.

SEIXO, Maria Alzira (org.). Dicionário da obra de António Lobo Antunes. Lisboa: Imprensa Nacional Casa da Moeda, 2008.

SELIGMANN-SILVA, Márcio (Org.). Leituras de Walter Benjamin. São Paulo: FAPESP, Annablume, 2007.

\section{Resumo}

Este artigo possui como objeto de estudo a representação da memória presente no livro Sôbolos rios que vão, de António Lobo Antunes (2010). A memória, despertada pelo medo da morte, traz à tona o menino que algum dia o senhor Antunes foi: o Antoninho. Contando com a contribuição de teóricos como Bachelard, Freud e Halbwachs, analisaremos trechos específicos do romance e procuraremos confrontar o texto antuniano obtendo dele múltiplos olhares.

\section{Abstract}

The focus of this study is the representation of memories in Sôbolos Rios Que Vão (ANTUNES, 2010). Fear of death brings forth the memory of the boy he once was: little Antoninho. Employing theories from Bachelard, Freud and Halbwachs, we analyze specific sections of the book and obtain multiple perspectives of the text of António Lobo Antunes. 